\title{
Cytokine Expression of Cord and Adult Blood Mononuclear Cells in Response to Streptococcus agalactiae
}

\author{
REINHARD BERNER, PATRICK WELTER, AND MATTHIAS BRANDIS \\ University Children's Hospital, D-79106 Freiburg, Germany
}

\begin{abstract}
Neonatal bacterial sepsis is often characterized by a fulminant clinical course and highly elevated plasma levels of proinflammatory cytokines. To evaluate in vitro activation of the neonatal immune system by specific infectious stimuli, cord blood cells from healthy neonates were examined for expression of tumor necrosis factor- $\alpha$ (TNF- $\alpha$ ), IL- $1 \beta$, IL-6, and IL-8 in response to Streptococcus agalactiae (GBS), lipopolysaccharide (LPS), and lipoteichoic acid (LTA). Cytokine-expression was compared in mononuclear cells from cord and adult peripheral blood. TNF- $\alpha$ and IL-6 levels in the supernatant of cord blood cell cultures were significantly higher after stimulation with heat-killed GBS $\left(10^{7} / \mathrm{mL}\right)$ than with LPS $(2 \mu \mathrm{g} / \mathrm{mL})$ or LTA $(2 \mu \mathrm{g} / \mathrm{mL})(\mathrm{TNF}-\alpha$ : 2215 versus 267.5 versus $40 \mathrm{pg} / \mathrm{mL}, p=0.001$; IL-6: 9667 versus 4909 versus $919 \mathrm{pg} / \mathrm{mL}, p=0.006)$. mRNA expression of TNF- $\alpha$, IL- $1 \beta$, IL-6, and IL-8 was equally pronounced after stimulation with either GBS, LPS, or LTA in cord or adult blood cells at various times. A MAb directed against the monocyte receptor molecule CD14 did not inhibit the release of cytokines
\end{abstract}

\section{ABSTRACT}

in cord blood mononuclear cells after stimulation with GBS. In summary, activation of cord blood cells by infectious stimuli is comparable to the adult immune response in terms of expression of proinflammatory cytokines. GBS in particular proves to be a potent activator of the neonatal immune system when compared with LPS and LTA. CD14 seems not to be a crucial molecule for activation of cord blood cells by GBS. (Pediatr Res 51: 304-309, 2002)

$\quad$ Abbreviations
ABMNC, adult blood mononuclear cells
CBMNC, cord blood mononuclear cells
GBS, group B streptococci
HBSS, Hanks' Balanced Salt Solution
IFN- $\boldsymbol{\gamma}$, interferon- $\gamma$
LPS, lipopolysaccharide
LTA, lipoteichoic acid
TNF- $\boldsymbol{\alpha}$, tumor necrosis factor- $\alpha$

Bacterial sepsis is a leading cause of neonatal morbidity and mortality (1). It occurs in the neonatal period far more frequently than in any period in later life. Streptococcus agalactiae (GBS) in particular is the most important single pathogen, accounting for as much as one third to one half of all cases of neonatal early onset sepsis $(2,3)$. The increased susceptibility of the newborn for septic infections appears to be related mainly to developmental deficiencies of the host defense system. These include a delayed maturation of the specific humoral and cellular immune response of neonatal B and T cells, defective activation of the complement system, and deficiencies of the myelopoietic system (4-6). Moreover, a decreased in vitro secretion of cytokines such as TNF- $\alpha$, IFN- $\gamma$, IL- $1 \beta$, IL-6, IL-8, and IL-12 has been described by several authors, and has been suggested to play a major role in susceptibility to overwhelming bacterial infections (7-10). Other groups, in

Received January 9, 2001; accepted July 17, 2001.

Correspondence and reprint requests: Reinhard Berner, M.D., University Children's Hospital, Mathildenstrasse 1, D-79106 Freiburg, Germany; e-mail: berner@kikli.ukl.uni-freiburg.de

Supported in part by grants from the Deutsche Forschungsgemeinschaft (Be 1756/2-1). contrast, have described a strong expression of IL-6, IL-12, and TNF- $\alpha$ by neonatal mononuclear cells (11-14). Furthermore, it has been reported by several groups including our own that in case of neonatal sepsis, cytokine plasma levels and gene expression in vivo are extraordinarily high, and even more elevated than in patients with sepsis beyond the neonatal period $(15,16)$. In addition, it was demonstrated in the murine system that T-cell-dependent neonatal immune functions are virtually comparable with those of adults (17).

Understanding of the pathogenesis of Gram-positive sepsis in both adults and infants is far less elaborate than that of the LPS-induced septic shock caused by Gram-negative bacteria $(18,19)$. Likewise, the mechanisms by which Gram-positive bacteria cause the release of proinflammatory cytokines such as TNF- $\alpha$, IL- $1 \beta$, or IL- 6 from human neonatal cells are not very clear. Gram-positive cell wall components such as LTA (2022) and, more recently, DNA of Gram-positive bacteria displaying a relative abundance of unmethylated $\mathrm{CpG}$-motifs have been suggested to contribute to the activation of the macrophage/monocyte system (23). Some recent studies also have investigated the role of GBS in activating the immune system. 
Several groups have reported a high cytokine production of human decidual cells and mononuclear blood cells in response to different cell wall components of GBS $(13,24-26)$. Williams et al. (14) described an even increased release of TNF- $\alpha$ from neonatal cells after stimulation with GBS compared with that from adults. Yachie et al. (10) reported that cord blood cells of term neonates produced high levels of IL-6 after stimulation with infectious stimuli including GBS, although a reduced IL-6 expression of cells from preterm neonates in response to GBS was observed. More recently, Kwak et al. (26) suggested from their data on GBS-induced intracellular and extracellular cytokine production an important role of TNF- $\alpha$, IFN- $\gamma$, and IL-12 in the pathogenesis of GBS infection. Medvedev et al. (27) demonstrated the involvement of CD14 and complement receptors CR3 and CR4 in nuclear factor- $\kappa \mathrm{B}$ activation and TNF- $\alpha$ production by GBS. In the present study, we aimed to compare the expression of TNF- $\alpha$, IL-1 $\beta$, IL-6, and IL-8 in cord and adult blood cells in response to stimulation by GBS, LPS, and LTA. Our hypothesis was that - in view of the very high cytokine levels in cord blood in vivo - the ability of cord blood cells to react on stimulation by GBS should at least equal that of peripheral blood cells from adults and, furthermore, should be as high as after stimulation with LPS or LTA. The involvement of CD14, an important receptor molecule of the innate immune system, was analyzed for its contribution to the in vitro cytokine response of cord blood cells after stimulation with GBS.

\section{METHODS}

Blood samples. Peripheral blood was obtained by venipuncture from healthy adult volunteers, in accordance with the principles of the Declaration of Helsinki. Blood samples from the umbilical cords of the placentas of healthy, full-term infants after scheduled cesarean section or vaginal delivery were obtained by puncture of the cord immediately after delivery. Newborns did not show any sign of bacterial infection during a follow-up of $1 \mathrm{wk}$. The samples were collected in heparinized syringes and processed within $2 \mathrm{~h}$ of collection. Parental informed consent was obtained for every patient before entry in the study. The study was approved by the local ethics committee.

Isolation of ABMNC and CBMNC. Before preparation by Ficoll-Hypaque gradients, cord blood was diluted 1:1 by endotoxin-free HBSS (GIBCO BRL, Eggenstein, Germany). Mononuclear cells were separated from whole blood by sedimentation on Ficoll-Hypaque gradients (density, $1.077 \mathrm{~g} / \mathrm{mL}$; GIBCO BRL) for $30 \mathrm{~min}$. The cells were washed twice with endotoxin-free HBSS and resuspended for culture in RPMI 1640 culture medium (GIBCO BRL) supplemented with $10 \%$ heat-inactivated FCS (GIBCO BRL). Mononuclear cells were purified by this method to homogeneity of $>90 \%$. Cell viability, as measured by trypan blue exclusion, was $>99 \%$. The cells were plated at a density of $1 \times 10^{6}$ cells $/ \mathrm{mL}$ in culture medium.

Bacteria. The strain of GBS (B954/92) used for stimulation experiments was isolated from the blood of a full-term neonate who had died of septic shock. The strain belongs to serotype Ib and bears the gene of the $\beta$ antigen of the $\mathrm{C}$ protein complex. Bacteria were grown in brain heart infusion broth for 6 to $8 \mathrm{~h}$, and collected during the logarithmic bacterial growth phase. Bacteria were washed several times in endotoxin-free HBSS, and then stocked in $30 \%$ glycerol at $-70^{\circ} \mathrm{C}$. All reagents, tips, and tubes were free of endotoxin as indicated by the manufacturers. For stimulation experiments, bacterial stocks were thawed, washed several times in endotoxin-free HBSS, and then diluted up to the appropriate concentration. Colonyforming units were determined for each experiment by serial dilution and plating on Mueller-Hinton agar. For the respective experiments, bacteria were heat-killed by incubating at $60^{\circ} \mathrm{C}$ for $45 \mathrm{~min}$.

Stimulation experiments. Cells were stimulated with LPS (from Escherichia coli O111:B4; Sigma Chemical Company, St. Louis, MO, U.S.A.) at $2 \mu \mathrm{g} / \mathrm{mL}$, LTA (from Streptococcus pyogenes; Sigma Chemical Co.) at $2 \mu \mathrm{g} / \mathrm{mL}$, viable bacteria at a concentration of $10^{4} / \mathrm{mL}$, and heat-killed bacteria at $10^{7} / \mathrm{mL}$. After $2,6,24$, and $48 \mathrm{~h}$ of incubation at $37^{\circ} \mathrm{C}$ with a $5 \% \mathrm{CO}_{2}$ atmosphere, cells were harvested and lysed in a buffer containing guanidium thiocyanate, sodium citrate, sarkosyl, and mercaptoethanol for RNA analysis. After 6 and $24 \mathrm{~h}$, the cell culture supernatant was collected and stored at $-30^{\circ} \mathrm{C}$ until further use. For control experiments, lower concentrations of LPS were used ranging from $10 \mathrm{pg} / \mathrm{mL}$ to $10 \mathrm{ng} / \mathrm{mL}$.

Preincubation with anti-CD14 MAb. CBMNC and ABMNC were incubated 45 min before bacterial stimulation with the MAb MY4 $(10 \mu \mathrm{g} / \mathrm{mL}$; Coulter Immunotech Diagnostics, Hamburg, Germany) directed against the CD14 molecule of monocytes. Stimulation was performed thereafter with LPS, LTA, and GBS as described above.

RNA isolation and reverse transcription. Total RNA was prepared using a phenol-chloroform extraction method as described by Chomczynski and Sacchi (28). RNA precipitates were pelleted at $4{ }^{\circ} \mathrm{C}$, washed once with $75 \%$ ethanol in diethylpyrocarbonate-treated distilled water and repelleted at 12,000 $\times g$ for $10 \mathrm{~min}$. Pellets were resuspended in $40 \mu \mathrm{L}$ of diethylpyrocarbonate-treated distilled water. The reverse transcriptase reaction was performed as described in detail recently (15), using Moloney murine leukemia virus reverse transcriptase (Superscript, GIBCO BRL, Life Technologies, Eggenstein, Germany). Resulting cDNA was stored at $-30^{\circ} \mathrm{C}$ until further use.

PCR-assisted $m \boldsymbol{R N A}$ amplification. Five microliters of cDNA was amplified by PCR as described previously (16) using the respective primer pairs and PCR conditions given by Bouaboula et al. (29). The expected sizes of the PCR products of the cellular cDNA were 237 bp for $\beta$-actin, $268 \mathrm{bp}$ for $\beta 2$-microglobulin, $263 \mathrm{bp}$ for IL- $1 \beta, 427 \mathrm{bp}$ for TNF- $\alpha, 260 \mathrm{bp}$ for IL-6, and 247 bp for IL-8. Specificity of the amplified bands was validated by their predicted size. Contamination with genomic DNA could be excluded as the primers used surround splice sites in the cellular targets. Therefore, genomic DNA contamination can be detected by different sizes of the amplification products. In addition, control PCR reaction was performed with total RNA that had not been subjected to the reverse transcriptase reaction. Cellular samples were considered to be evaluable when mRNA of $\beta$-actin was detectable. 
For semiquantitative evaluation of cytokine expression, mRNA expression was scaled from 0 to 6 , and normalized to the expression of $\beta$-actin, as described previously (16). Cytokine mRNA levels are given as mean \pm SD.

IL-6 and TNF- $\alpha$ ELISA. Frozen aliquots of cell culture supernatants were thawed on ice at the time of analysis. Cytokine concentrations were measured by a double-sandwich ELISA technique using a commercial kit specific for IL-6 and TNF- $\alpha$ (Milenia, DPC Biermann, Bad Nauheim, Germany). The detection limit of the assay as indicated by the manufacturer was 15.6 and $6.0 \mathrm{pg} / \mathrm{mL}$, respectively. Duplicate measurements were performed for each sample. Samples were diluted before analysis as necessary. Dilution buffer was provided by the manufacturer. To reduce the variability owing to donor variation, the cytokine concentrations in supernatants of unstimulated cells were subtracted from the values obtained after stimulation.

Statistical methods. Differences of cytokine gene expression in CBMNC after stimulation with LPS, heat-killed GBS, and viable GBS were tested by ANOVA. Differences between the mean values of mRNA levels in ABMNC versus CBMNC were analyzed by unpaired $t$ test. Differences between the median values of cytokine levels in the cell culture supernatants were analyzed by the Kruskal-Wallis test (one-way ANOVA). Probability values indicated for the differences between two individual groups were calculated using the Wilcoxon-Mann-Whitney test. Analyses were performed using the SPSS-software package (SPSS, Chicago, IL, U.S.A.). All $p$ values were calculated by two-tailed distribution. Differences were considered significant at $p<0.05$.

\section{RESULTS}

IL-6 concentrations in supernatants of CBMNC and ABMNC. IL-6 concentrations were elevated in supernatants of
CBMNC $(n=8)$ after stimulation for $24 \mathrm{~h}$ with heat-killed GBS when compared with stimulation with LPS or LTA ( $p=$ 0.006; Table 1). In ABMNC $(n=5)$, this difference did not reach statistical significance $(p=0.811$; Table 1$)$. There was no significant difference when cytokine secretion of CBMNC was compared with that of ABMNC after stimulation with LPS, GBS, or LTA (Table 1). When IL-6 levels were compared after a 6-h period of stimulation with those after $24 \mathrm{~h}$, no significant increase was observed in ABMNC (data not shown). Likewise, no increase was found after stimulation of CBMNC with LPS or LTA (data not shown). However, when CBMNC were stimulated with GBS, IL-6 levels increased significantly after an incubation period of 6 and $24 \mathrm{~h}$ from 2008.5 to $9667 \mathrm{pg} / \mathrm{mL}(p=0.029)$.

TNF- $\alpha$ concentrations in supernatants of $C B M N C$ and $\boldsymbol{A B M N C}$. Likewise, TNF- $\alpha$ concentrations in CBMNC were significantly higher after stimulation for $24 \mathrm{~h}$ with GBS than with LPS or LTA ( $p=0.001$; Table 1$)$. This was not true in ABMNC ( $p=0.958$; Table 1$)$. When comparing stimulation experiments in CBMNC after an incubation period of only $6 \mathrm{~h}$, TNF- $\alpha$ expression was likewise higher after stimulation with GBS than after stimulation with LPS and LTA (1236.5 versus 335.5 versus $149 \mathrm{pg} / \mathrm{mL}, p=0.011)$. This difference at $6 \mathrm{~h}$ was not observed in ABMNC (data not shown). There was no difference in TNF- $\alpha$ secretion between ABMNC and CBMNC after stimulation with GBS, LPS, or LTA (Table 1).

Preincubation with anti-CD14 MAb (MY4). When CBMNC or ABMNC were preincubated with the anti-CD14 antibody and stimulated with GBS, LPS, or LTA, no statistically significant difference was observed between preincubated and nonpreincubated cells (Table 2). Interestingly, there was an increased rather than a reduced cytokine expression after preincubation with the MY4 antibody in CBMNC stimulated with GBS (Table 2); this difference, however, did not reach statis-

Table 1. Concentrations of IL-6 and TNF- $\alpha$ in the supernatants of ABMNC $(n=5)$ and CBMNC $(n=8)$ after 24-h coincubation with LPS, LTA, and heat-killed GBS

\begin{tabular}{|c|c|c|c|c|c|c|}
\hline & \multirow{2}{*}{$\begin{array}{c}\text { LPS } \\
(2 \mu \mathrm{g} / \mathrm{mL})\end{array}$} & \multirow{2}{*}{$\begin{array}{c}\text { LTA } \\
(2 \mu \mathrm{g} / \mathrm{mL})\end{array}$} & \multirow{2}{*}{$\begin{array}{c}\text { GBS } \\
\left(1 \times 10^{7} / \mathrm{mL}\right)\end{array}$} & \multicolumn{3}{|c|}{$p$ values } \\
\hline & & & & GBS $v s$ LPS & GBS $v s$ LTA & Kruskal-Wallis \\
\hline \multicolumn{7}{|l|}{ IL-6 (pg/mL) } \\
\hline median & 2410 & 1720 & 1990 & NS & NS & NS \\
\hline quartiles & $555.5-3269.5$ & $426.5-4965$ & $873-12787.5$ & & & \\
\hline \multicolumn{7}{|l|}{ CBMNC } \\
\hline median & 4909 & 919 & 9667 & $0.04 *$ & $0.028^{*}$ & $0.006 *$ \\
\hline \multicolumn{7}{|c|}{ ABMNC vs CBMNC } \\
\hline$p$ values & NS & NS & NS & & & \\
\hline \multicolumn{7}{|c|}{ TNF- $\alpha(\mathrm{pg} / \mathrm{mL})$} \\
\hline \multicolumn{7}{|c|}{ ABMNC } \\
\hline median & 112 & 141.5 & 267 & NS & NS & NS \\
\hline quartiles & $13-538$ & $4-534$ & $53.5-15990.5$ & & & \\
\hline \multicolumn{7}{|l|}{ CBMNC } \\
\hline \multicolumn{7}{|c|}{ ABMNC vs CBMNC } \\
\hline
\end{tabular}

* Indicated are the differences among the three groups as analyzed by the Kruskal-Wallis test (one-way ANOVA) and the differences between the individual groups (Wilcoxon-Mann-Whitney test). 
Table 2. Concentrations of IL-6 and TNF- $\alpha$ in the supernatants of ABMNC $(n=5)$ and CBMNC $(n=8)$ after 24-h stimulation with LPS, LTA, and heat-killed GBS, with and without preincubation with the anti-CD14 antibody (MY4)

\begin{tabular}{lcrr}
\hline & LPS $(2 \mu \mathrm{g} / \mathrm{mL})$ & LTA $(2 \mu \mathrm{g} / \mathrm{mL})$ & GBS $\left(1 \times 10^{7} / \mathrm{mL}\right)$ \\
\hline IL-6 $(\mathrm{pg} / \mathrm{mL})$ median (quartiles) & & & \\
ABMNC & $2410(555.5-3269.5)$ & $867(0-4965)$ & $1990(873-12787.5)$ \\
+ MY4 & $5445(937.8-14804.8)$ & $531(0-4670)$ & $1720(0-14311)$ \\
CBMNC & $4909(1387.5-6813.8)$ & $919(134.3-3862.5)$ & $9667(6303-15006)$ \\
+ MY4 & $2974(487.8-17311.8)$ & $65.4(0-226.8)$ & $8324.5(2418.3-14216)$ \\
TNF- $\alpha$ (pg/mL) median (quartiles) & $112(13-538)$ & & \\
ABMNC & $381(0-3521.3)$ & $24(4-475.3)$ & $267(53.5-15990.5)$ \\
+ MY4 & $267.5(49-440.5)$ & $0(0-1243)$ & $9897(661-24642.5)$ \\
CBMNC & $1038(252-1395)$ & $40(2.5-141.3)$ & $2117(1535.5-3086)$ \\
+ MY4 & $172(0-344)$ & $6858(1382-20449)$ \\
\hline
\end{tabular}

* Differences between incubation with or without MY4 in the individual groups were not statistically significant (Wilcoxon-Mann-Whitney test).

tical significance. Only when comparing the LTA-induced release of IL-6 in CBMNC with and without MY4 preincubation, the activation seemed to be blocked, but the difference again was not statistically significant (919 versus $65.4 \mathrm{pg} / \mathrm{mL}$; $p=0.05)$. To exclude intrinsic activating properties of MY4, CBMNC were incubated with the antibody alone at different incubation periods. The baseline secretion of IL- 6 and TNF- $\alpha$ after $6 \mathrm{~h}$ of incubation was 7.5 and $1.65 \mathrm{pg} / \mathrm{mL}$ (with control values without preincubation subtracted). Similar results were obtained after $24 \mathrm{~h}$ (data not shown). Furthermore, we tested the blocking activities of the antibody at different concentrations of LPS, which were well below the concentration of 2 $\mu \mathrm{g} / \mathrm{mL}$ that was used for the stimulation experiments in comparison to GBS and LTA. In a series of experiments with cord blood cells, the IL- 6 concentration was $35.1 \mathrm{pg} / \mathrm{mL}$ after $6 \mathrm{~h}$ of incubation with $10 \mathrm{pg} / \mathrm{mL}$ LPS, $1612 \mathrm{pg} / \mathrm{mL}$ after stimulation with $100 \mathrm{pg} / \mathrm{mL}$ LPS, $15,484 \mathrm{pg} / \mathrm{mL}$ with $1 \mathrm{ng} / \mathrm{mL}$ LPS, and $26,966 \mathrm{pg} / \mathrm{mL}$ with $10 \mathrm{ng} / \mathrm{mL}$ LPS. In comparison, after preincubation with the MY4 antibody, IL-6 was $7 \mathrm{pg} / \mathrm{mL}$ at 10 $\mathrm{pg} / \mathrm{mL}$ LPS, $8.7 \mathrm{pg} / \mathrm{mL}$ at $100 \mathrm{pg} / \mathrm{mL}$ LPS, $37.6 \mathrm{pg} / \mathrm{mL}$ at 1 $\mathrm{ng} / \mathrm{mL}$ LPS, and $271 \mathrm{pg} / \mathrm{mL}$ at $10 \mathrm{ng} / \mathrm{mL}$ LPS. These findings confirmed the blocking activity of the antibody, which, however, diminished with increasing concentrations of LPS. Similar results were obtained after $24 \mathrm{~h}$ of incubation.

Cytokine gene expression after stimulation of CBMNC with GBS and LPS. Corresponding to the ELISA results, cytokine mRNA expression after stimulation with GBS was comparable with that after stimulation with LPS at either time; no statistically significant difference was observed between either stimulatory agent (Table 3). A rapid increase in mRNA transcription of IL- $1 \beta$, IL- 6 , IL- 8 , and TNF- $\alpha$ was observed beginning $2 \mathrm{~h}$ after incubation with heat-killed bacteria. When CBMNC were cocultivated with viable bacteria at concentrations of $10^{4} / \mathrm{mL}$, cytokine expression increased more slowly than after stimulation with LPS or heat-killed GBS at $10^{7} / \mathrm{mL}$; it reached comparable levels after $6 \mathrm{~h}$, and decreased rapidly after an incubation period of 24 and $48 \mathrm{~h}$. At these times, bacterial growth had resulted in a bacterial concentration of $10^{7} / \mathrm{mL}$ and $10^{8} / \mathrm{mL}$, respectively. Viability of CBMNC - as microscopically evaluated - at these incubation periods had decreased, but still the majority $(90 \%)$ of cells were viable. Nevertheless, bacterial growth probably affected cytokine expression, which markedly decreased.
When comparing cytokine gene expression in cord and adult peripheral blood cells, no significant difference was detected, neither after stimulation with GBS nor with LPS, demonstrating also on the transcriptional level that the immune response in neonatal cells is as elaborate as in adult cells. For example, after stimulation with LPS for $24 \mathrm{~h}$, gene expression of IL- $1 \beta$ was $4.5 \pm 1.9$ in cord blood, and $4.6 \pm 0.57$ in adult blood (NS); after stimulation with GBS for $24 \mathrm{~h}$, gene expression of IL- $1 \beta$ was $4.1 \pm 1.75$ in cord blood, and $4.3 \pm 1.15$ in adult blood (NS). The same was true for IL-6, IL-8, and TNF- $\alpha$ (data not shown).

Table 3. Gene expression of $I L-1 \beta, I L-6, I L-8$, and $T N F-\alpha$ in CBMNC after 0, 2, 6, 24, and 48 h of stimulation with LPS (2 $\mu \mathrm{g} / \mathrm{mL})$, heat-killed $G B S\left(1 \times 10^{7} / \mathrm{mL}\right)$, and viable GBS $(1 \times$ $\left.10^{4} / \mathrm{mL}\right) *$

\begin{tabular}{|c|c|c|c|c|}
\hline & Control & LPS & $\begin{array}{c}\text { GBS } \\
\text { heat-killed }\end{array}$ & $\begin{array}{c}\text { GBS } \\
\text { viable }\end{array}$ \\
\hline $0 \mathrm{~h}$ & $n=12$ & & & \\
\hline IL-1 $\beta$ & $2.9 \pm 1.73$ & & & \\
\hline IL-6 & $0 \pm 0$ & & & \\
\hline IL-8 & $2.8 \pm 1.6$ & & & \\
\hline TNF- $\alpha$ & $0 \pm 0$ & & & \\
\hline $2 \mathrm{~h}$ & $n=13$ & $n=12$ & $n=13$ & $n=11$ \\
\hline IL-1 $\beta$ & $2.6 \pm 1.6$ & $4.6 \pm 1.44$ & $4.1 \pm 1.8$ & $2.2 \pm 2.22$ \\
\hline IL-6 & $0 \pm 0$ & $1.7 \pm 1.78$ & $0.9 \pm 1.19$ & $0 \pm 0$ \\
\hline IL-8 & $3.5 \pm 1.37$ & $4.0 \pm 1.28$ & $4.0 \pm 1.15$ & $2.73 \pm 1.42$ \\
\hline TNF- $\alpha$ & $0 \pm 0$ & $0.9 \pm 1.51$ & $1.8 \pm 2.13$ & $0.2 \pm 0.4$ \\
\hline $6 \mathrm{~h}$ & $n=12$ & $n=13$ & $n=13$ & $n=10$ \\
\hline IL-1 $\beta$ & $3 \pm 2.25$ & $4.9 \pm 1.75$ & $4.9 \pm 1.89$ & $4.1 \pm 2.18$ \\
\hline IL-6 & $0 \pm 0$ & $3.3 \pm 2.46$ & $3.1 \pm 1.8$ & $1.8 \pm 1.93$ \\
\hline IL-8 & $3.5 \pm 1.38$ & $4.5 \pm 0.97$ & $4.3 \pm 1.18$ & $3.2 \pm 1.61$ \\
\hline TNF- $\alpha$ & $0.1 \pm 0.29$ & $0.2 \pm 0.6$ & $2.2 \pm 2.03$ & $1.7 \pm 2.36$ \\
\hline $24 \mathrm{~h}$ & $n=12$ & $n=13$ & $n=13$ & $n=8$ \\
\hline IL- $1 \beta$ & $1.2 \pm 1.7$ & $4.5 \pm 1.9$ & $4.1 \pm 1.75$ & $0.8 \pm 1.77$ \\
\hline IL-6 & $0 \pm 0$ & $1.1 \pm 1.34$ & $1.6 \pm 1.5$ & $0 \pm 0$ \\
\hline IL-8 & $2.5 \pm 1.5$ & $3.3 \pm 1.1$ & $3.9 \pm 0.95$ & $1.3 \pm 2.05$ \\
\hline TNF- $\alpha$ & $0 \pm 0$ & $0.2 \pm 0.37$ & $0 \pm 0$ & $0 \pm 0$ \\
\hline $48 \mathrm{~h}$ & $n=12$ & $n=12$ & $n=13$ & $n=7$ \\
\hline IL-1 $\beta$ & $1 \pm 1.54$ & $3.5 \pm 2.40$ & $3.5 \pm 2.26$ & $1.6 \pm 2.7$ \\
\hline IL-6 & $0 \pm 0$ & $1.3 \pm 1.61$ & $1.2 \pm 1.59$ & $0 \pm 0$ \\
\hline IL-8 & $1.8 \pm 1.59$ & $3.4 \pm 1.88$ & $3.4 \pm 1.56$ & $1.6 \pm 2.37$ \\
\hline TNF- $\alpha$ & $0 \pm 0$ & $0.3 \pm 0.87$ & $0.2 \pm 0.55$ & $0 \pm 0$ \\
\hline
\end{tabular}

* Mean \pm SD is indicated. Likewise the number $(n)$ of CBMNC samples analyzed in each stimulation experiment is indicated. Differences among the four groups were analyzed by the Kruskal-Wallis test (one-way ANOVA). No statistically significant differences were observed; thus no post hoc analysis was performed. 


\section{DISCUSSION}

Recently, we have reported that cytokine plasma levels in cord blood are highly elevated in neonates with early onset sepsis compared with those of nonseptic neonates (15). In addition, we could show that mRNA expression in cord blood samples of septic neonates also was highly increased, indicating that cytokine production is endogenous to the neonate (16). In the present study, we investigated the in vitro capability of cord blood cells to react on stimulation with GBS, the bacterial pathogen mainly involved in neonatal sepsis $(2,3)$. Previously, Yachie et al. (10) reported that whole blood cultures from cord blood of term neonates produced high levels of IL-6 after stimulation with infectious stimuli. Likewise, Peat et al. (30) observed that neonatal culture-derived macrophages produced significantly more TNF- $\alpha$ in response to GBS than adult cells. Although in our study the difference between CBMNC and ABMNC was not statistically significant, we could confirm a highly up-regulated expression of proinflammatory cytokines in response to heat-killed and viable GBS on the mRNA as well as on the protein level. Moreover, whereas Yachie et al. (10) found a significantly higher cytokine response after stimulation with $E$. coli and the Gram-negative cell wall component LPS than after stimulation with GBS and Listeria monocytogenes, we found a more pronounced IL- 6 and TNF- $\alpha$ expression in cord blood cells after stimulation with GBS than with LPS or LTA. This difference was not observed in adult cells, which might reflect the increased susceptibility of the neonatal host to this particular pathogen. Williams et al. (14) observed similar results when comparing the production of TNF- $\alpha$ in mixed mononuclear cells from neonates and adults. They found a significantly higher cytokine expression in neonatal cells after stimulation with GBS, although the response to phytohemagglutinin was not significantly different. These findings fit well with the clinical observation that severely affected newborns with GBS infection suffer from fulminant septic shock (15), which is supposed to be a TNF- $\alpha$ - and IL-6mediated event (18). The findings of our study support the evidence that in the neonatal setting, Gram-positive bacteriaand GBS in particular - induce an at least comparably strong expression of proinflammatory cytokines as does endotoxin in Gram-negative sepsis.

We also showed a rapid increase of mRNA expression of proinflammatory cytokines; heat-killed GBS stimulated cord blood cells as rapidly and vigorously as did LPS. The rapid kinetics of cytokine expression induced by whole heat-killed GBS suggests that the innate immune system contributes significantly to the immunologic response of neonatal cells to Gram-positive pathogens. Activation of the immune and inflammatory responses by Gram-negative organisms is known to be mediated by the Toll-like receptor 4 and the CD14 molecule on monocytes, which is the receptor for the LPSbinding protein (19). There is some evidence that Grampositive cell wall components such as peptidoglycan fragments or LTA likewise are bound by CD14, and might use an LPS-like activation pathway $(20,31,32)$. We therefore investigated the effect of the anti-CD14 antibody MY4 in both CBMNC and ABMNC after stimulation with LPS, LTA, and
GBS. Because in previous studies on monocyte activation and receptor involvement, LPS doses of 1 up to $10 \mu \mathrm{g} / \mathrm{mL}$ have been used $(14,27,32,33)$, we also chose to perform our comparative experiments with a dose of $2 \mu \mathrm{g} / \mathrm{mL}$ LPS, consciously having in mind the reduced blocking capacities of the antibody against LPS activation at this dose. Likewise, LTA doses of 0.05 to $5 \mu \mathrm{g} / \mathrm{mL}$ have been used in experiments with streptococcal LTA, inducing a release of proinflammatory cytokines in cultured human monocytes similar to those observed after LPS stimulation $(21,22)$. Although several components isolated from GBS such as LTA, type-specific polysaccharides, and the group B antigen seem to use CD14dependent pathways (31), activation and cytokine release of CBMNC induced by whole heat-killed GBS could not be blocked by the anti-CD14 antibody in our experiments. However, we observed some blocking activity of the anti-CD14 antibody against streptococcal LTA. We speculate from these findings that an alternative way of activation of cord blood cells is used by GBS that is not CD14 dependent. Bacterial factors other than structural components of the cell wall, e.g. hemolysins and other exotoxins, might be of a yet underestimated relevance for the induction of cytokine release by GBS. Further investigation is needed to elucidate these activating mechanisms on a molecular basis, both on the bacterial and on the host's side.

In conclusion, we demonstrated in this study that GBS is a very potent activator of the neonatal immune system. The susceptibility of neonatal immune cells to GBS seems to be increased when compared with LPS and LTA. The immune response of cord blood cells to bacterial pathogens is as strong as the adult immune response in terms of the expression of TNF- $\alpha$, IL- $1 \beta$, IL- 6 , and IL- 8 . However, the mechanisms of activation and the signal transduction pathways in GBSstimulated neonatal blood cells still remain to be elucidated.

Acknowledgment. The authors thank Heike Staedtler and Silvia Duerre for their excellent technical assistance.

\section{REFERENCES}

1. Schrag SJ, Zywicki S, Farley MM, Reingold AL, Harrison LH, Lefkowitz LB, Hadler JL, Danila R, Cieslak PR, Schuchat A 2000 Group B streptococcal disease in the era of intrapartum prophylaxis. N Engl J Med 342:15-20

2. Berner R, Schumacher RF, Bartelt S, Forster J, Brandis M 1998 Bacteremia in hospitalized children: predisposing conditions and case-related microorganisms. Eur J Clin Microbiol Infect Dis 17:337-340

3. Gladstone IM, Ehrenkranz RA, Edberg SC, Baltimore RS 1990 A ten-year review of neonatal sepsis and comparison with the previous fifty-year experience. Pediatr Infect Dis J 9:819-825

4. Cairo MS 1989 Neonatal neutrophil host defense. Am J Dis Child 143:40-56

5. Chalmers IMH, Janossy G, Contreras M, Navarrete C 1998 Intracellular cytokine profile of cord and adult blood lymphocytes. Blood 92:11-18

6. Lewis DB, Wilson CB 1995 Developmental immunology and role of host defenses in neonatal susceptibility to infection. In: Remington JS, Klein JO (eds) Infectious Diseases of the Fetus and Newborn Infant, 4th Ed. Saunders, Philadelphia, pp 20-99

7. Rowen JL, Smith CW, Edwards MS 1995 Group B streptococci elicit leukotriene B4 and interleukin- 8 from human monocytes: neonates exhibit a diminished response. J Infect Dis 172:420-426

8. Schibler KR, Liechty KW, White WL, Rothstein G, Christensen RD 1992 Defective production of interleukin- 6 by monocytes: a possible mechanism underlying several host deficiencies of neonates. Pediatr Res 31:18-21

9. Weatherstone K, Rich E 1989 Tumor necrosis factor/cachectin and interleukin-1 secretion by cord blood monocytes from premature and term neonates. Pediatr Res 25:342-346

10. Yachie A, Takano N, Ohta K, Uehara T, Fujita S, Miyawaki T, Taniguchi N 1992 Defective production of IL-6 in very small premature infants in response to bacterial pathogens. Infect Immun 60:749-753 
11. Schultz C, Rott C, Richter N, Bucsky P, Reiss I, Gortner L 1999 Intracytoplasmic detection of cytokines in neonatal lymphocytes and monocytes by flow cytometry. Blood 93:3566-3567

12. Scott ME, Kubin M, Kohl S 1997 High level interleukin-12 production, but diminished interferon- $\gamma$ production, by cord blood mononuclear cells. Pediatr Res 41:547-553

13. Vallejo JG, Baker CJ, Edwards MS 1996 Interleukin-6 production by human neonatal monocytes stimulated by type III group B streptococci. J Infect Dis 174:332-337

14. Williams PA, Bohnsack JF, Augustine NH, Drummond WK, Rubens CE, Hill HR 1993 Production of tumor necrosis factor by human cells in vitro and in vivo, induced by group B streptococci. J Pediatr 123:292-300

15. Berner R, Niemeyer CM, Leititis JU, Funke A, Schwab C, Rau U, Richter K, Tawfeek MSK, Clad A, Brandis M 1998 Plasma levels and gene-expression of G-CSF, TNF- $\alpha$, IL-1 $\beta$, IL-6, IL-8, and sICAM-1 in neonatal early-onset sepsis. Pediatr Res 44:469477

16. Berner R, Tüxen B, Clad A, Forster J, Brandis M 2000 Elevated gene-expression of interleukin-8 in cord blood is a sensitive marker of neonatal infection. Eur J Pediatr 159:205-210

17. Ridge JP, Fuchs EJ, Matzinger P 1996 Neonatal tolerance revisited: turning on newborn T cells with dendritic cells. Science 271:1723-1726

18. Sáez-Llorens X, McCracken GH Jr 1992 Sepsis syndrome and septic shock in pediatrics: current concepts of terminology, pathophysiology, and management. J Pediatr 123:497-508

19. Landmann R, Knopf HP, Link S, Sansano S, Schumann R, Zimmerli W 1996 Human monocyte CD14 is upregulated by lipopolysaccharide. Infect Immun 64:1762-1769

20. Dunne DW, Resnick D, Greenberg J, Krieger M, Joiner KA 1994 The type I macrophage scavenger receptor binds to gram-positive bacteria and recognizes lipoteichoic acid. Proc Natl Acad Sci USA 91:1863-1867

21. Bhakdi S, Klonisch T, Nuber P, Fischer W 1991 Stimulation of monokine production by lipoteichoic acids. Infect Immun 59:4614-4620

22. Keller R, Fischer W, Keist R, Bassetti S 1992 Macrophage response to bacteria: induction of marked secretory and cellular activities by lipoteichoic acids. Infect Immun 60:3664-3672

23. Sparwasser T, Miethke T, Lipford G, Erdmann A, Häcker H, Heeg K, Wagner H 1997 Macrophages sense pathogens via DNA motifs: induction of tumor necrosis factoralpha-mediated shock. Eur J Immunol 27:1671-1679
24. Dudley DJ, Edwin SS, van Wagones J, Augustine NH, Hill HR, Mitchell MD 1997 Regulation of decidual cell chemokine production by group B streptococci and purified bacterial cell wall components. Am J Obstet Gynecol 177:666-672

25. von Hunolstein C, Totolian A, Alfrarone G, Mancusoa G, Cucumano V, Teti G, Orefici G 1997 Soluble antigens from group B streptococci induce cytokine production in human blood cultures. Infect Immun 65:4017-4021

26. Kwak DJ, Augustine NH, Borges WG, Joyner JL, Green WF, Hill HR 2000 Intracellular and extracellular cytokine production by human mixed mononuclear cells in response to group B streptococci. Infect Immun 68:320-327

27. Medvedev AE, Flo T, Ingalls RR, Golenbock DT, Teti G, Vogel SN, Espevik T 1998 Involvement of CD14 and complement receptors CR3 and CR4 in nuclear factor-B activation and TNF production induced by lipopolysaccharide and group B streptococcal cell walls. J Immunol 160:4535-4542

28. Chomczynski P, Sacchi N 1987 Single-step method of RNA isolation by acid guanidium thiocyanate-phenol-chloroform extraction. Anal Biochem 162:156163

29. Bouaboula M, Legoux P, Pességué, Delpech B, Dumont X, Piechaczyk M, Casellas P, Shire D 1992 Standardization of mRNA titration using a polymerase chain reaction method involving co-amplification with a multispecific internal control. J Biol Chem 267:21830-21838

30. Peat EB, Augustine NH, Drummond WK, Bohnsack JF, Hill HR 1995 Effects of fibronectin and group B streptococci on tumour necrosis factor- $\alpha$ production by human culture-derived macrophages. J Immunol 84:440-445

31. Cuzzola M, Mancuso G, Beninati C, Biondo C, von Hunolstein C, Orefici G, Espevik T, Flo T, Teti G 2000 Human monocyte receptors involved in tumor necrosis factor responses to group B streptococcal products. Infect Immun 68:994-998

32. Cuzzola M, Mancuso G, Beninati C, Biondo C, Genovese F, Tomasello F, Flo TH, Espevik T, Teti G $2000 \beta 2$ integrins are involved in cytokine responses to whole gram-positive bacteria J Immunol 164:5871-5876

33. Flo TH, Halaas O, Lien E, Ryan L, Teti G, Golenbock DT, Sundan A, Espevik T 2000 Human Toll-like receptor 2 mediates monocyte activation by Listeria monocytogenes, but not by group B streptococci or lipopolysaccharide. J Immunol 164:2064-2069 